\title{
Nutrient Requirement for the Degradation of Cellulose to Methane by a Mixed Population of Anaerobes
}

\author{
By A. W. KHAN, T. M. TROTTIER, G. B. PATEL AND S. M. MARTIN \\ Division of Biological Sciences, National Research Council of Canada, \\ Ottawa, Ontario K1A OR6, Canada
}

(Received 4 December 1978)

\begin{abstract}
A synthetic medium containing inorganic sources of $\mathrm{N}, \mathrm{P}, \mathrm{Fe}, \mathrm{S}, \mathrm{Ca}^{2+}$ and $\mathrm{Mg}^{2+}$, trace minerals and essential vitamins was developed for anaerobic degradation of cellulose to $\mathrm{CH}_{4}$. A mixed culture obtained from sewage sludge and grown in batch culture in this medium degraded about $4 \mathrm{~g}$ cellulose $1^{-1}$ week $^{-1}$ and produced about $710 \mathrm{ml}$ total gas per $\mathrm{g}$ cellulose degraded. The gas produced contained between 51 and $56 \% \mathrm{CH}_{4}$, the remainder being $\mathrm{CO}_{2}$. For maximum degradation of cellulose to $\mathrm{CH}_{4}$ and $\mathrm{CO}_{2}$, the requirement for essential salts other than $\mathrm{HCO}_{3}^{-}$, Fe and $\mathrm{S}^{2-}$ was comparable to that of other anaerobes. $\mathrm{NH}_{4}{ }^{+}$or $\mathrm{Na}_{2} \mathrm{CO}_{3}$ at 20 to $24 \mathrm{~mm}$ and total $\mathrm{Fe}$ at 0.4 to $0.6 \mathrm{~mm}$ gave optimum conversion of cellulose to $\mathrm{CH}_{4}$, while the inclusion of additional $\mathrm{S}^{2-}$ in the presence of $1.75 \mathrm{mM}^{-} \mathrm{SO}_{4}{ }^{2-}$ was not required.
\end{abstract}

\section{INTRODUCTION}

As part of a broader study of the conversion of cellulose to $\mathrm{CH}_{4}$ and the micro-organisms involved in the process, a microbial ecosystem obtained from sewage sludge was maintained in the laboratory and tested for its ability to degrade various kinds of cellulose found in waste and to form methane (Khan, 1977). In these tests a synthetic medium generally used for the isolation and maintenance of anaerobes was used. However, cellulose degradation was slow and the yields of total gas and $\mathrm{CH}_{4}$, respectively, were about 40 and $50 \%$ of the theoretical values based on stoicheiometry, $n \mathrm{C}_{6} \mathrm{H}_{12} \mathrm{O}_{6} \rightarrow 3 n \mathrm{CH}_{4}+3 n \mathrm{CO}_{2}$. These comparatively poor yields of gas were not unexpected since, amongst the various factors controlling symbiotic-metabolic interaction between different species of micro-organisms present in an ecosystem, the composition of the medium is of prime importance in substrate utilization. For example, earlier work on washed cells obtained from this ecosystem has shown that the concentration as well as the nature of the sulphur source has a profound effect on the overall efficiency of the system (Khan \& Trottier, 1978). Therefore, the work was extended to study the effect of various nutrients in the basal medium on the process and to deiermine their concentrations for optimum degradation of cellulose to methane.

\section{METHODS}

Culture maintenance. The culture was established from an inoculum obtained from a municipal digester by growth in a 301 fermenter at $35^{\circ} \mathrm{C}$ under anaerobic conditions. The culture was maintained under the 'repeated-fed batch culture' technique (Pirt, 1975) in a chemically defined medium (Table 1, medium II) containing trace minerals and vitamins but devoid of cysteine $/ \mathrm{Na}_{2} \mathrm{~S}$. The repeated-fed batch culture technique was used because of the difficulty involved in the continuous feeding of an insoluble substrate such as cellulose. This fermenter was fed at weekly intervals with cellulose at the rate of $1 \mathrm{~g} \mathrm{l}^{-1}$ week $^{-1}$ and medium was withdrawn to give a microbial residence time of 24 to 30 weeks. Under these conditions, the fermenter maintained a chemical oxygen demand (COD) of $3470( \pm 412) \mathrm{mg} \mathrm{l}^{-1}$, a volatile acid content of 0 to $10 \mathrm{mg}^{-1}$ 
and a $\mathrm{pH}$ value of $6 \cdot 9 \pm 0 \cdot 2$. The stability of this ecosystem with respect to these parameters and its ability to degrade cellulose and form methane over a period of 2 years indicated that the culture was well-established (Khan, 1977). Fermenter samples were filtered through six layers of cheesecloth to remove any undegraded cellulose and used as a subsequent inoculum. All procedures were carried out under an atmosphere of $\mathrm{N}_{2} /$ $\mathrm{CO}_{2}(4: 1, \mathrm{v} / \mathrm{v})$; the gas mixture was passed over heated copper catalyst to remove traces of $\mathrm{O}_{2}$ immediately before use.

Media and test conditions. The composition of the synthetic media tested are reported in Table 1. The effects of $\mathrm{N}, \mathrm{P}, \mathrm{HCO}_{3}{ }^{-}, \mathrm{CO}_{3}{ }^{2-}, \mathrm{Cl}^{-}, \mathrm{S}^{2-}$ and $\mathrm{Fe}$ on the degradation of cellulose to $\mathrm{CH}_{4}$ were studied by omitting the appropriate cation or anion from the medium and by adding it back in various concentrations. Since the volume of the inoculum formed $50 \%$ of the total volume of the medium in these tests, the inoculum was analysed for the cations and anions under investigation, and the medium composition was adjusted to compensate for the carry-over ingredients. In all cases, the cellulose content and the concentration of trace minerals and vitamins were kept constant.

Experiments were carried out in $160 \mathrm{ml}$ serum vials (Miller \& Wolin, 1974) containing $250 \mathrm{mg}$ cellulose (acid washed, ashless), $20 \mathrm{ml}$ of solution containing the desired amounts of salts and vitamins and $25 \mathrm{ml}$ of inoculum. The medium was supplemented by anaerobically injecting $4 \mathrm{ml}$ of water (control) or $4 \mathrm{ml}$ of an aqueous solution containing the desired amount of cation or anion. Cysteine/ $\mathrm{Na}_{2} \mathrm{~S}$ solution or $\mathrm{Na}_{2} \mathrm{~S}$ solution alone (usually $1 \mathrm{ml}$ per vial) was also introduced in a similar way whenever required. The volume of medium in each vial was always $50 \mathrm{ml}$. All solutions and water used in these tests were equilibrated and stored under $\mathrm{N}_{2} / \mathrm{CO}_{2}$. Either $\mathrm{N}_{2} / \mathrm{CO}_{2}(4: 1, \mathrm{v} / \mathrm{v})$ or $\mathrm{H}_{2} / \mathrm{CO}_{2}(4: 1, \mathrm{v} / \mathrm{v})$ was used to maintain an anaerobic atmosphere inside the vials. A head-space atmosphere of $\mathrm{H}_{2} / \mathrm{CO}_{2}$ was used to determine the effects of test ingredients on the methanogenesis occurring as a result of $\mathrm{CO}_{2}$ reduction. The volumes and composition of gases produced from cellulose degradation were corrected for the initial head-space gases. All vials were incubated at $35^{\circ} \mathrm{C}$ with shaking. Results are averages for at least three tests carried out on different occasions. All tests were run in duplicate.

Since the inoculum derived from the stock culture contained a fairly high concentration of $\mathrm{Fe}$ in the form of insoluble FeS, which could not be removed readily, the inoculum was analysed for total Fe content and tested for its ability to degrade cellulose to $\mathrm{CH}_{4}$ in an Fe-free medium. After incubation for 3 to 6 weeks, the fermenter liquid was analysed for Fe content and used as an inoculum for the next batch. This procedure was continued for up to six transfers using Fe-free medium each time. A control, containing Fe at the concentrations present in the initial inoculum, was concurrently run to rule out the possibility of any change in the inoculum.

Redox potential $\left(E_{\mathrm{h}}\right)$ was measured using a platinum/calomel electrode combination. Under the test conditions, $E_{\mathrm{h}}$ values of the medium were below $-350 \mathrm{mV}$. The $\mathrm{pH}$ of the medium was generally between 6.7 and 7.0. Small quantities of propionic or butyric acids, occasionally detected in the fermenter liquids, were equated on a $1: 1$ basis with acetic acid for tabulation purposes.

Methods of analysis. Analyses were done to determine the volume and composition of gas in the headspace, the volatile acids and cellulose content of the fermenter liquids and the $\mathrm{N}, \mathrm{P}, \mathrm{Fe}, \mathrm{Cl}^{-}, \mathrm{HCO}_{3}^{-}$and $\mathrm{CO}_{3}{ }^{2-}$ contents of the inoculum. Gas volume was measured by a gas manometer. Gas composition was assayed according to van Huyssteen (1967) and volatile acids according to Ackman (1972) using gas chromatography. Details of these methods have been reported by Khan \& Trottier (1978). For analyses, the total contents of each vial were centrifuged at $6000 \mathrm{~g}$ for $20 \mathrm{~min}$. The supernate was retained for the estimation of volatile acids, cations and anions. The pellet was washed three times by centrifugation and resuspension in water, dissolved in $72 \% \mathrm{H}_{2} \mathrm{SO}_{4}$ and the cellulose content was determined using the anthrone reagent (Herbert et al., 1971). The supernate (described above) was used for the determination of $\mathrm{N}$ by the microKjeldahl technique, $\mathrm{P}$ by 1-amino-2-naphthol-4-sulphonic acid, $\mathrm{Fe}$ by 1,10-phenanthroline, and $\mathrm{Cl}^{-}$by $\mathrm{Hg}\left(\mathrm{NO}_{3}\right)_{2}$ as described by Orland (1965). Chemical oxygen demand (COD) determinations were made on well-mixed samples (Orland, 1965).

\section{RESULTS AND DISCUSSION}

The mineral composition of some of the defined media used for the isolation, characterization, cultivation and maintenance of anaerobes is given in Table 1. The nitrogen, phosphate, $\mathrm{Ca}^{2+}, \mathrm{Mg}^{2+}, \mathrm{Cl}^{-}$and trace minerals and vitamin requirements of the mixed culture capable of degrading cellulose to $\mathrm{CH}_{4}$ were basically the same as those of anaerobes of rumen (Bryant \& Robinson, 1961; Caldwell \& Bryant, 1966) and sewage (Kugelman \& Chin, 1971) origin. Nitrogen from 3.5 to $38.0 \mathrm{~mm}$ and phosphate from 1.5 to $12.0 \mathrm{~mm}$ had little or no effect on the ability of the culture to degrade cellulose to $\mathrm{CH}_{4}$. Since nitrogen at 
Table 1. Mineral and vitamin composition of media

All media were prepared according to Holdeman \& Moore (1973) and contained $1 \mathrm{mg}$ resazurin $1^{-1}$. Medium I was that described by Balch \& Wolfe (1976), medium II by Bryant \& Robinson (1961) and Caldwell \& Bryant (1966), and medium III by Zeikus (1977).

\begin{tabular}{|c|c|c|c|c|c|}
\hline \multirow[b]{2}{*}{$\begin{array}{c}\text { Solution } \\
\text { no. }\end{array}$} & \multirow[b]{2}{*}{ Ingredients } & \multicolumn{4}{|c|}{ Media } \\
\hline & & I & $\begin{array}{l}\text { II } \\
\text { (mg }\end{array}$ & $\underset{\left.\mathrm{ml} \mathrm{II}^{-1}\right)}{\mathrm{III}}$ & IV \\
\hline 1 & $\mathrm{~K}_{2} \mathrm{HPO}_{4}$ & 450 & 296 & 1106 & 296 \\
\hline 2 & $\begin{array}{l}\mathrm{KH}_{2} \mathrm{PO}_{4} \\
\mathrm{NH}_{4} \mathrm{Cl} \\
\left(\mathrm{NH}_{4}\right)_{2} \mathrm{SO}_{4} \\
\mathrm{MgSO}_{4} \cdot 7 \mathrm{H}_{2} \mathrm{O} \\
\mathrm{MgCl}_{2} \cdot \mathrm{H}_{2} \mathrm{O} \\
\mathrm{CaCl} 2.2 \mathrm{H}_{2} \mathrm{O} \\
\mathrm{NaCl}\end{array}$ & $\begin{array}{l}\frac{450}{7} \\
450 \\
\frac{180}{12} \\
900\end{array}$ & $\begin{array}{l}\frac{180}{750} \\
90 \\
-60 \\
45\end{array}$ & $\begin{array}{l}750 \\
900 \\
= \\
200 \\
=\end{array}$ & $\begin{array}{r}180 \\
680 \\
150 \\
90 \\
-60 \\
-\end{array}$ \\
\hline 3 & $\begin{array}{l}\mathrm{Na}_{2} \mathrm{CO}_{3} \\
\mathrm{NaHCO}_{3}\end{array}$ & $\overline{2500}$ & $\frac{4000}{-}$ & - & $\overrightarrow{2060}$ \\
\hline 4 & $\begin{array}{l}\mathrm{FeSO}_{4} \cdot 7 \mathrm{H}_{2} \mathrm{O} \\
\mathrm{FeCl}_{2} \cdot 4 \mathrm{H}_{2} \mathrm{O}\end{array}$ & $-^{2}$ & 20 & 二 & $\begin{array}{r}20 \\
-*\end{array}$ \\
\hline 5 & Trace mineral solution $(\mathrm{v} / \mathrm{v})$ & 一 & - & $9 \dagger$ & 10 \\
\hline 6 & Vitamin solution $(\mathrm{v} / \mathrm{v})$ & - & 一 & $5 \S$ & $10 \|$ \\
\hline 7 & $\begin{array}{l}\mathrm{Na}_{2} \mathrm{~S} .9 \mathrm{H}_{2} \mathrm{O} \text { I } \\
\text { Cysteine. HCl. } \mathrm{H}_{2} \mathrm{O}\end{array}$ & $\begin{array}{l}500 \\
500\end{array}$ & $\begin{array}{l}250 \\
250\end{array}$ & 500 & 二 \\
\hline
\end{tabular}

* Added to bring the total Fe concentration of the inoculated medium to $0.4 \mathrm{~mm}$ when required.

$\dagger$ Trace mineral solution contained $\left(\mathrm{mg} \mathrm{l}^{-1}\right)$ : nitrilotriacetic acid, $4500 ; \mathrm{FeCl}_{2} .4 \mathrm{H}_{2} \mathrm{O}, 400 ; \mathrm{MnCl}_{2} .4 \mathrm{H}_{2} \mathrm{O}$, $100 ; \mathrm{CoCl}_{2} .6 \mathrm{H}_{2} \mathrm{O}, 170 ; \mathrm{ZnCl}_{2}, 100 ; \mathrm{CaCl}_{2}, 20 ; \mathrm{H}_{3} \mathrm{BO}_{3}, 19 ; \mathrm{Na}_{2} \mathrm{MoO}_{4} .2 \mathrm{H}_{2} \mathrm{O}, 10$.

† Trace mineral solution was prepared according to Wolin et al. (1963) and contained (mg $\left.1^{-1}\right)$ : nitrilotriacetic acid, 1500; $\mathrm{MgSO}_{4} .7 \mathrm{H}_{2} \mathrm{O}, 3000 ; \mathrm{MnSO}_{4} . \mathrm{H}_{2} \mathrm{O}, 500 ; \mathrm{NaCl}, 1000 ; \mathrm{FeSO}_{4} .7 \mathrm{H}_{2} \mathrm{O}, 100 ; \mathrm{CoCl}_{2} .6 \mathrm{H}_{2} \mathrm{O}$, $100 ; \mathrm{CaCl}_{2} .2 \mathrm{H}_{2} \mathrm{O}, 100 ; \mathrm{ZnSO}_{4} .7 \mathrm{H}_{2} \mathrm{O}, 100 ; \mathrm{CuSO}_{4} .5 \mathrm{H}_{2} \mathrm{O}, 10 ; \mathrm{AlK}\left(\mathrm{SO}_{4}\right)_{2} .12 \mathrm{H}_{2} \mathrm{O}, 10 ; \mathrm{H}_{3} \mathrm{BO}_{3}, 10 ; \mathrm{Na}_{2} \mathrm{MoO}_{4}$. $2 \mathrm{H}_{2} \mathrm{O}, 10$.

$\S$ Prepared according to Bryant et al. (1959).

|| Vitamin solution was prepared according to Wolin et al. (1963) and contained $\left(\mathrm{mg}^{-1}\right)$ : pyridoxine. $\mathrm{HCl}$, 10 ; thiamin. $\mathrm{HCl}, 5$; riboflavin, 5 ; nicotinic acid, 5 ; $p$-aminobenzoic acid, 5 ; biotin, 2 ; folic acid, 2 ; vitamin $\mathrm{B}_{12}, 0 \cdot 5$.

If Cysteine/sulphide solution prepared according to Holdeman \& Moore (1973).

$22 \mathrm{~mm}$ inhibits the growth of pure cultures of methanogens (Hobson \& Shaw, 1976), we chose a nitrogen concentration of $15 \mathrm{~mm}$ which is comparable to that recommended for methanogens (Zeikus, 1977). Phosphate at $3 \mathrm{~mm}$ is recommended for growing rumen anaerobes (Bryant \& Robinson, 1961; Caldwell \& Bryant, 1966) and we used this concentration in further studies. These values gave a $\mathrm{N} / \mathrm{P}$ ratio of $5: 1$ which is comparable to the proportions of these elements found in microbial cells (Luria, 1960). Since various pure and mixed cultures obtained from other ecosystems have been shown to tolerate fairly high levels of N, P, $\mathrm{Mg}^{2+}, \mathrm{Ca}^{2+}, \mathrm{Na}^{+}, \mathrm{K}^{+}$and $\mathrm{Cl}^{-}$(Hobson \& Shaw, 1976; Patel \& Roth, 1977; Kugelman \& Chin, 1971), no attempts were made to study the toxic levels of these nutrients on this ecosystem. The toxic levels of $\mathrm{Na}^{+}, \mathrm{K}^{+}, \mathrm{Ca}^{2+}$ and $\mathrm{Mg}^{2+}$, respectively, were $300 \mathrm{mM}$, 150 to $200 \mathrm{~mm}, 125$ to $150 \mathrm{~mm}$ and $125 \mathrm{~mm}$ for an anaerobic waste treatment process (Kugelman \& Chin, 1971). For methanogens, $\mathrm{Cl}^{-}$above $97 \mathrm{~mm}$ inhibits growth (Patel \& Roth, 1977).

The optimum concentration of $\mathrm{HCO}_{3}-$ for the degradation of cellulose to $\mathrm{CH}_{4}$ was between 16 and $24 \mathrm{~mm}$ (Fig. 1). At higher concentrations, $\mathrm{HCO}_{3}{ }^{-}$depressed this process. Replacement of the optimum concentration of $\mathrm{HCO}_{3}{ }^{-}$by the same concentration of $\mathrm{CO}_{3}{ }^{2-}$ inhibited both cellulose degradation and methane formation during the first week of incubation (Table 2). However, the deleterious effects of $\mathrm{CO}_{3}{ }^{2-}$ on both of these parameters 
Table 2. Effect of sulphide, bicarbonate and carbonate on cellulose degradation and methane formation by mixed cultures

The basic medium was medium IV without $\mathrm{NaHCO}_{3}$ and $\mathrm{Na}_{2} \mathrm{~S}$; it was supplemented with $\mathrm{NaHCO}_{3}$ (24 mM), $\mathrm{Na}_{2} \mathrm{CO}_{3}(24 \mathrm{mM})$ and $\mathrm{Na}_{2} \mathrm{~S}(0.5 \mathrm{~mm})$ as indicated. The gas phase was $\mathrm{H}_{2} / \mathrm{CO}_{2}(4: 1, \mathrm{v} / \mathrm{v})$. The initial cellulose content was $5 \mathrm{~g}^{-1}(27 \cdot 8 \mathrm{~mm}$ as glucose equivalents).

\begin{tabular}{|c|c|c|c|c|c|c|}
\hline \multirow[b]{2}{*}{ Addition(s) } & \multirow[b]{2}{*}{$\begin{array}{c}\text { Incubation } \\
\text { time } \\
\text { (weeks) }\end{array}$} & \multicolumn{2}{|c|}{ Cellulose breakdown } & \multicolumn{3}{|c|}{ Methane formation $\dagger$} \\
\hline & & $(\mathrm{mM})^{*}$ & $\begin{array}{c}(\% \text { of } \\
\text { initial value })\end{array}$ & $(\mathrm{mM})$ & $\begin{array}{c}(\% \text { of } \\
\text { total gas })\end{array}$ & $\begin{array}{l}\text { [mol }(\mathrm{mol} \\
\left.\text { glucose })^{-1}\right]\end{array}$ \\
\hline $\begin{array}{l}\text { None (control) } \\
\mathrm{NaHCO}_{3} \\
\mathrm{Na}_{2} \mathrm{CO}_{3} \\
\mathrm{Na}_{2} \mathrm{~S} \\
\mathrm{NaHCO}_{3}+\mathrm{Na}_{2} \mathrm{~S} \\
\mathrm{Na}_{2} \mathrm{CO}_{3}+\mathrm{Na}_{2} \mathrm{~S}\end{array}$ & $\begin{array}{l}1 \\
1 \\
1 \\
1 \\
1 \\
1\end{array}$ & $\begin{array}{r}18 \cdot 3 \\
23 \cdot 6 \\
19 \cdot 3 \\
19 \cdot 0 \\
19 \cdot 0 \\
8 \cdot 7\end{array}$ & $\begin{array}{l}66 \\
85 \\
69 \\
68 \\
68 \\
31\end{array}$ & $\begin{array}{l}43 \cdot 8 \\
43 \cdot 9 \\
32 \cdot 5 \\
49 \cdot 1 \\
40 \cdot 4 \\
17 \cdot 5\end{array}$ & $\begin{array}{l}51 \\
45 \\
44 \\
54 \\
51 \\
49\end{array}$ & $\begin{array}{l}2 \cdot 4 \\
1 \cdot 9 \\
1 \cdot 7 \\
2 \cdot 6 \\
2 \cdot 1 \\
2 \cdot 0\end{array}$ \\
\hline $\begin{array}{l}\text { None (control) } \\
\mathrm{NaHCO}_{3} \\
\mathrm{Na}_{2} \mathrm{CO}_{3} \\
\mathrm{Na}_{2} \mathrm{~S} \\
\mathrm{NaHCO}_{3}+\mathrm{Na}_{2} \mathrm{~S} \\
\mathrm{Na}_{2} \mathrm{CO}_{3}+\mathrm{Na}_{2} \mathrm{~S}\end{array}$ & $\begin{array}{l}2 \\
2 \\
2 \\
2 \\
2 \\
2\end{array}$ & $\begin{array}{l}20 \cdot 9 \\
27 \cdot 0 \\
26 \cdot 5 \\
23 \cdot 2 \\
27 \cdot 5 \\
27 \cdot 3\end{array}$ & $\begin{array}{l}75 \\
97 \\
95 \\
84 \\
99 \\
98\end{array}$ & $\begin{array}{l}57 \cdot 0 \\
69 \cdot 3 \\
65 \cdot 8 \\
67 \cdot 5 \\
71 \cdot 9 \\
69 \cdot 3\end{array}$ & $\begin{array}{l}52 \\
51 \\
51 \\
54 \\
54 \\
53\end{array}$ & $\begin{array}{l}2 \cdot 7 \\
2 \cdot 6 \\
2 \cdot 5 \\
2 \cdot 9 \\
2 \cdot 6 \\
2 \cdot 5\end{array}$ \\
\hline
\end{tabular}

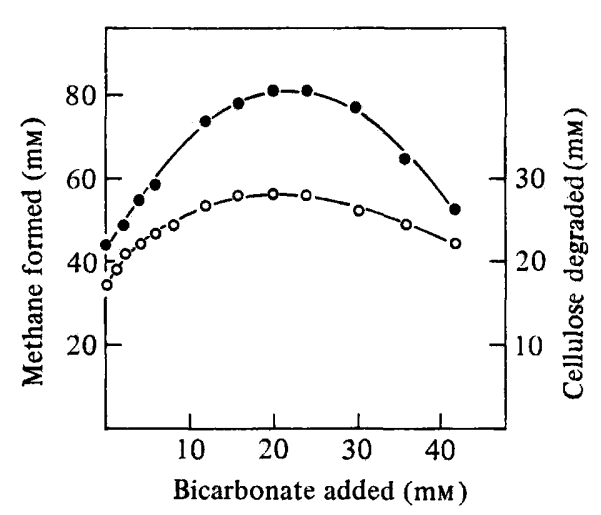

Fig. 1

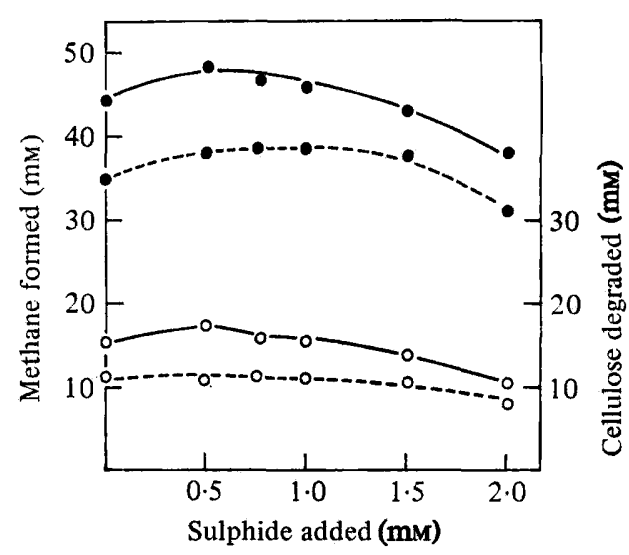

Fig. 2

Fig. 1. Effect of $\mathrm{NaHCO}_{3}$ on cellulose degradation (O) and $\mathrm{CH}_{4}$ formation (O) by mixed cultures in medium IV. The initial cellulose concentration was $5 \mathrm{~g}^{-1}(27.8 \mathrm{mM}$ as glucose equivalents); the head-space gas was $\mathrm{H}_{2} / \mathrm{CO}_{2}$; and cultures were incubated for 2 weeks.

Fig. 2. Effect of $\mathrm{Na}_{2} \mathrm{~S}$ on cellulose degradation $(O)$ and $\mathrm{CH}_{4}$ formation $(O)$ by mixed cultures in medium IV with (-) or without $(---) \mathrm{NaHCO}_{3}$. The initial cellulose concentration was $5 \mathrm{~g} \mathrm{l}^{-1}$ ( $27.8 \mathrm{mM}$ as glucose equivalents); the head-space gas was $\mathrm{H}_{2} / \mathrm{CO}_{2}$; and the cultures were incubated for 1 week.

disappeared during subsequent incubation. A higher than optimum concentration of $\mathrm{HCO}_{3}{ }^{-}$ has also been shown to cause a decrease in the number of colonies of rumen anaerobes recovered from such media (Caldwell \& Bryant, 1966). However, the inhibitory effect of $\mathrm{CO}_{3}{ }^{2-}$ in the initial stages of fermentation was not due to differences in initial $\mathrm{pH}$. The $\mathrm{HCO}_{3}{ }^{-} / \mathrm{CO}_{2}$ buffer system appears to be more effective than the $\mathrm{CO}_{3}{ }^{2-} / \mathrm{CO}_{2}$ buffer in the degradation of cellulose to $\mathrm{CH}_{4}$ by mixed cultures. The importance of the $\mathrm{HCO}_{3}-/ \mathrm{CO}_{2}$ 
Table 3. Effect of iron content of the medium on cellulose degradation, acid accumulation and gas formation by mixed cultures

The basic medium was medium IV without $\mathrm{Fe}$; $\mathrm{FeSO}_{4}$ was added to give the required $\mathrm{Fe}$ concentrations. The gas phase was $\mathrm{H}_{2} / \mathrm{CO}_{2}(4: 1, \mathrm{v} / \mathrm{v})$. The initial cellulose content was $5 \mathrm{~g}^{-1}(27.8 \mathrm{mM}$ as glucose equivalents).

\begin{tabular}{|c|c|c|c|c|c|c|}
\hline \multirow[b]{2}{*}{$\begin{array}{c}\text { Fe content* } \\
(\mathrm{mM})\end{array}$} & \multirow[b]{2}{*}{$\begin{array}{c}\text { Incubation } \\
\text { time } \\
\text { (weeks) }\end{array}$} & \multirow{2}{*}{$\begin{array}{l}\text { Cellulose } \\
\text { breakdown } \\
(\mathrm{mm}) \dagger\end{array}$} & \multirow{2}{*}{$\begin{array}{l}\text { Acid } \\
\text { accumu- } \\
\text { lation } \\
(\mathrm{mm}) \ddagger\end{array}$} & \multirow{2}{*}{$\begin{array}{l}\text { Total } \\
\text { gas } \\
\text { formation } \\
\text { (mM) }\end{array}$} & \multicolumn{2}{|c|}{ Methane formation } \\
\hline & & & & & $(\mathrm{mM})$ & $\begin{array}{l}\text { [mol (mol } \\
\left.\text { glucose })^{-1}\right]\end{array}$ \\
\hline 0.60 & 2 & $22 \cdot 6$ & $<1$ & $132 \cdot 4$ & $72 \cdot 8$ & $3 \cdot 2$ \\
\hline 0.50 & 2 & $22 \cdot 7$ & $<1$ & $128 \cdot 1$ & $70 \cdot 2$ & $3 \cdot 1$ \\
\hline 0.40 & 2 & $21 \cdot 8$ & $<1$ & $128 \cdot 1$ & 64.9 & 3.0 \\
\hline $0.20 \S$ & 3 & $21 \cdot 2$ & $9 \cdot 0$ & $126 \cdot 2$ & $60 \cdot 1$ & $2 \cdot 8$ \\
\hline $0.10 \S$ & 4 & $19 \cdot 3$ & $19 \cdot 2$ & $112 \cdot 8$ & $48 \cdot 4$ & $2 \cdot 4$ \\
\hline $0.05 \S$ & 5 & 18.0 & $21 \cdot 9$ & $109 \cdot 6$ & $43 \cdot 7$ & $2 \cdot 4$ \\
\hline $0.02 \S$ & 6 & $17 \cdot 6$ & 38.0 & $106 \cdot 1$ & $42 \cdot 0$ & $2 \cdot 4$ \\
\hline
\end{tabular}

* Fe content of medium plus inoculum.

$\dagger$ Expressed as glucose equivalents.

$\$$ Total acids, expressed as acetic acid equivalents.

$\S$ Addition of $\mathrm{Fe}$ to increase total content to $0.4 \mathrm{mM}$ quantitatively restored the ability of the inoculum to degrade cellulose and form methane.

buffer in media used for the isolation, enumeration and growth of anaerobes is well known (Bryant, 1959).

Sulphide concentrations of up to $0.5 \mathrm{~mm}$ in medium containing $1.75 \mathrm{~mm}^{-\mathrm{SO}_{4}}{ }^{2-}$ had little or no beneficial effect on the degradation of cellulose to $\mathrm{CH}_{4}$ (Fig. 2) but above $0.5 \mathrm{~mm}, \mathrm{~S}^{2-}$ inhibited $\mathrm{CH}_{4}$ formation and above $0.8 \mathrm{~mm}$ it inhibited both cellulose degradation and $\mathrm{CH}_{4}$ formation. The inhibitory effects of $\mathrm{S}^{2-}$ on these parameters were more pronounced in medium containing $\mathrm{CO}_{3}{ }^{2-}$ than in medium containing $\mathrm{HCO}_{3}^{-}$(Table 2). However, the deleterious effects of higher concentrations of $\mathrm{S}^{2-}$ on cellulose degradation to $\mathrm{CH}_{4}$ disappeared during the second week of incubation, probably as a result of removal of $\mathrm{S}^{2-}$ as $\mathrm{H}_{2} \mathrm{~S}$ or FeS. Rumen micro-organisms (Emery et al., 1957) and cellulose-degrading anaerobes present in sewage sludge (Khan \& Trottier, 1978) utilize $\mathrm{SO}_{4}{ }^{2-}$ as a sulphur source, but all methanogenic bacteria studied to date use only $\mathrm{S}^{2-}$ as a sulphur source (Zeikus, 1977). Since in medium containing $\mathrm{SO}_{4}{ }^{2-}, \mathrm{S}^{2-}$ formed by the reduction of $\mathrm{SO}_{4}{ }^{2-}$ appears to serve as a sulphur source for the methanogens in mixed cultures (Khan \& Trottier, 1978), and since the inoculum appears to contain enough $\mathrm{S}^{2-}$ for the growth of methanogens, no additional $\mathrm{S}^{2-}$ was included in this medium.

A total $\mathrm{Fe}$ concentration in the medium of between 0.4 and $0.6 \mathrm{~mm}$ gave the best results for degradation of cellulose and production of $\mathrm{CH}_{4}$ (Table 3). At lower Fe concentrations, the cellulose degrading ability of cultures was greatly diminished and acids accumulated in the medium. Since these lower concentrations of $\mathrm{Fe}$ did not affect the ability of this culture to reduce $\mathrm{CO}_{2}$ to $\mathrm{CH}_{4}$, the accumulation of acids may indicate inhibition of the acetogenic phase at low $\mathrm{Fe}$ levels. These findings are in agreement with earlier work of Speece \& McCarty (1964) showing that the addition of $\mathrm{FeCl}_{3}$ at $0.6 \mathrm{~mm}$ lowered the concentrations of volatile acids accumulating in the digester. Iron is the least toxic of the common heavy metals and has no detrimental effects on anaerobic digestion up to $19.6 \mathrm{mM}$; above this concentration the toxic effects are minimal provided the $\mathrm{pH}$ of the medium is above 6.4 (Mosey \& Hughes, 1975).

The total Fe contents given in Table 3 include both soluble and insoluble $\mathrm{Fe}$, because it is difficult to remove precipitated Fe present in the inoculum and keep the Fe in a soluble state during incubation, particularly in mixed cultures. During the preparation of the medium, maintenance of strict anaerobic conditions is necessary to keep $0.3 \mathrm{~mm}$ or more Fe in solution. Under aerobic conditions, Fe present in the medium is precipitated as phos- 
Table 4. Effect of head-space gas and incubation time on cellulose degradation and gas formation in modified medium (IV) by mixed cultures

\begin{tabular}{|c|c|c|c|c|c|c|c|c|c|}
\hline \multirow[b]{2}{*}{$\begin{array}{c}\text { Incubation } \\
\text { time } \\
\text { (weeks) }\end{array}$} & \multirow{2}{*}{$\begin{array}{l}\text { Head-space } \\
\text { gas } \\
\text { mixture } \\
(v / v)\end{array}$} & \multicolumn{2}{|c|}{ Cellulose breakdown } & \multicolumn{3}{|c|}{ Methane formation } & \multicolumn{3}{|c|}{ Total gas formation } \\
\hline & & $(\mathrm{mM})^{*}$ & $\begin{array}{c}(\% \text { of initial } \\
\text { value } \dagger)\end{array}$ & $\begin{array}{c}\text { From } \\
\text { head-space } \\
\text { gas } f(\mathrm{mM})\end{array}$ & $\begin{array}{l}\text { From } \\
\text { cellulose§ } \\
(\mathrm{mM})\end{array}$ & 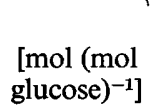 & $\begin{array}{l}\text { From } \\
\text { cellulose§ } \\
(\mathrm{mM})\end{array}$ & $\begin{array}{l}\text { [mol }(\mathrm{mol} \\
\left.\text { glucose })^{-1}\right]\end{array}$ & $\begin{array}{c}{[\mathrm{ml}(\mathrm{g}} \\
\left.\text { cellulose })^{-1}\right]\end{array}$ \\
\hline $\begin{array}{l}1 \\
1\end{array}$ & $\begin{array}{l}\mathrm{H}_{2} / \mathrm{CO}_{2}(4: 1) \\
\mathrm{N}_{2} / \mathrm{CO}_{2}(4: 1)\end{array}$ & $\begin{array}{l}15 \cdot 7 \\
21 \cdot 8\end{array}$ & $\begin{array}{l}57 \\
78\end{array}$ & $\underline{18 \cdot 0}$ & $\begin{array}{l}47 \cdot 4 \\
58 \cdot 8\end{array}$ & $\begin{array}{l}3 \cdot 0 \\
2 \cdot 7\end{array}$ & $\begin{array}{r}89 \cdot 5 \\
121 \cdot 1\end{array}$ & $\begin{array}{l}5 \cdot 7 \\
5 \cdot 6\end{array}$ & $\begin{array}{l}716 \\
708\end{array}$ \\
\hline $\begin{array}{l}2 \\
2\end{array}$ & $\begin{array}{l}\mathrm{H}_{2} / \mathrm{CO}_{2}(4: 1) \\
\mathrm{N}_{2} / \mathrm{CO}_{2}(4: 1)\end{array}$ & $\begin{array}{l}25 \cdot 6 \\
26 \cdot 7\end{array}$ & $\begin{array}{l}92 \\
96\end{array}$ & $\begin{array}{c}18 \cdot 0 \\
-\end{array}$ & $\begin{array}{l}78 \cdot 9 \\
76 \cdot 3\end{array}$ & $\begin{array}{l}3 \cdot 1 \\
2 \cdot 9\end{array}$ & $\begin{array}{l}142 \cdot 1 \\
149 \cdot 5\end{array}$ & $\begin{array}{l}5 \cdot 6 \\
5 \cdot 6\end{array}$ & $\begin{array}{l}704 \\
710\end{array}$ \\
\hline
\end{tabular}

* Expressed as glucose equivalents.

Initial cellulose concentration was $5 \mathrm{~g}^{-1}(27.8 \mathrm{~mm}$ as glucose equivalents)

$\ddagger$ Head-space gases occupied $110 \mathrm{ml}$ per vial at $37^{\circ} \mathrm{C}$. Calculations based on stoicheiometry: $4 \mathrm{H}_{2}+\mathrm{CO}_{2} \rightarrow \mathrm{CH}_{4}+2 \mathrm{H}_{2} \mathrm{O}$, at $25^{\circ} \mathrm{C}$.

$\S$ Total gas, or total $\mathrm{CH}_{4}$, minus $\mathrm{CH}_{4}$ formed from head-space gases. 
phate, carbonate or hydroxide. Even in medium prepared under strictly anaerobic conditions, and containing higher amounts of nitrilotriacetic acid as an Fe chelating agent, the $\mathrm{H}_{2} \mathrm{~S}$ formed as a result of reduction of $\mathrm{SO}_{4}{ }^{2-}$ by mixed cultures reacts with $\mathrm{Fe}^{2+}$ to form insoluble sulphide. The equilibrium that exists between soluble and insoluble Fe depends on many factors, e.g. $\mathrm{pH}$ changes occurring as a result of the formation of acids from cellulose degradation, and the presence of chelating compounds produced by the micro-organisms. Formation of FeS may have additional beneficial effects on this fermentation in (i) serving as a reducing agent (Brock \& O'Dea, 1977) and (ii) removing $\mathrm{H}_{2} \mathrm{~S}$ and $\mathrm{S}^{2-}$ which have toxic effects on both cellulose degradation (Khan $\&$ Trottier, 1978) and methanogenesis (Cappenberg, 1974).

Mixed cultures grown in the modified medium (Table 1, medium IV) degraded 92 to $96 \%$ of the cellulose present and gave total gas yields of about $710 \mathrm{ml}$ per g cellulose degraded (Table 4). The $\mathrm{CH}_{4}$ content of the gas was 51 to $56 \%$, the remainder being $\mathrm{CO}_{2}$. These yields were about $95 \%$ of the theoretical values based on stoicheiometry: $n \mathrm{C}_{6} \mathrm{H}_{12} \mathrm{O}_{6} \rightarrow$ $6 n\left(\mathrm{CH}_{4}+\mathrm{CO}_{2}\right)$. The remaining $5 \%$ carbon present in the cellulose, and probably some of the carbon supplied in the form of $\mathrm{HCO}_{3}^{-}$, appear to be converted to biomass. Cellulose breakdown during the first week of incubation was faster in an $\mathrm{N}_{2} / \mathrm{CO}_{2}$ atmosphere than in an $\mathrm{H}_{2} / \mathrm{CO}_{2}$ atmosphere (Table 4). However, during subsequent incubation, these differences disappeared. In tests using $\mathrm{H}_{2} / \mathrm{CO}_{2}$ as the head-space gas, the formation of $\mathrm{CH}_{4}$ from the head-space gases started in the first hour of incubation and was complete within $24 \mathrm{~h}$. Although after the initial $24 \mathrm{~h}$ of incubation there was little or no $\mathrm{H}_{2}$ left in the head-space, the possibility of initial contact of these organisms with $\mathrm{H}_{2}$ resulting in slower growth or a longer lag period cannot be ruled out. The presence of $\mathrm{H}_{2}$ during the initial $24 \mathrm{~h}$ did not affect the overall efficiency of the process.

This is paper no. 17367 of the NRCC.

\section{REFERENCES}

ACKman, R. G. (1972). Porous polymer bead packings and formic acid vapor in GLC of volatile fatty acids. Journal of Chromatographic Science $10,560-565$.

Balch, W. E. \& Wolfe, R. S. (1976). New approach to the cultivation of methanogenic bacteria: 2-mercaptoethanesulfonic acid (HS-CoM)dependent growth of Methanobacterium ruminantium in a pressurized atmosphere. Applied and Environmental Microbiology 32, 781-791.

Brock, T. D. \& O'DeA, K. (1977). Amorphous ferrous sulfide as a reducing agent for culture of anaerobes. Applied and Environmental Microbiology 33, 254-256.

BRYANT, M. P. (1959). Bacterial species of the rumen. Bacteriological Reviews 23, 125-153.

Bryant, M. P. \& Robinson, I. M. (1961). An improved non-selective culture medium for ruminal bacteria and its use in determining diurnal variation in number of bacteria in the rumen. Journal of Dairy Science 44, 1446-1456.

Bryant, M. P., Robinson, I. M. \& ChU, H. (1959). Observations on the nutrition of Bacteroides succinogenes-a ruminal cellulolytic bacterium. Journal of Dairy Science 42, 1831-1847.

Caldwell, D. R. \& Bryant, M. P. (1966). Medium without rumen fluid for nonselective enumeration and isolation of rumen bacteria. Applied Microbiology 14, 794-801.
CAPPenberG, T. E. (1974). Interrelations between sulfate-reducing and methane-producing bacteria in bottom deposits of a fresh water lake. 1. Field observations. Antonie van Leeuwenhoek 40, 285295.

Emery, R. S., Smith, C. K. \& Huffman, C. F. (1957). Utilization of inorganic sulfate by rumen microorganisms. 1. Incorporation of inorganic sulfate into amino acids. Applied Microbiology 5, 360-362.

Herbert, D., Phipps, P. J. \& Strange, R. E. (1971). Chemical analysis of microbial cells. Methods in Microbiology 7B, 209-344.

Hobson, P. N. \& SHAw, B. G. (1976). Inhibition of methane production by Methanobacterium formicicum. Water Research 10, 849-852.

Holdeman, L. V. \& Moore, W. E. C. (editors) (1973). Anaerobe Laboratory Manual, 2nd edn. Blacksburg, Va, U.S.A.: Anaerobe Laboratory, Virginia Polytechnic Institute and State University.

KHAN, A. W. (1977). Anaerobic degradation of cellulose by mixed culture. Canadian Journal of Microbiology 23, 1700-1705.

Khan, A. W. \& Trottier, T. M. (1978). Effect of sulfur containing compounds on anaerobic degradation of cellulose to methane by mixed culture obtained from sewage sludge. Applied and Environmental Microbiology 35, 1027-1037. 
Kugelman, J. J. \& Chin, K. K. (1971). Toxicity, synergism and antagonism in anaerobic waste treatment process. Advances in Chemistry Series $105,55-90$.

LURIA, S. E. (1960). The bacterial protoplasm: composition and organization. In The Bacteria, vol. 1, pp. 1-34. Edited by I. C. Gunsalus \& R. Y. Stanier. New York: Academic Press.

Miller, T. L. \& Wolin, M. J. (1974). A serum bottle modification of Hungate technique for cultivating obligate anaerobes. Applied Microbiology 27, 985-987.

Mosey, F. E. \& Hughes, D. A. (1975). The toxicity of heavy metal ions to anaerobic digestion. Water Pollution Control 74, 18-39.

ORLAND, H. P. (editor) (1965). Standard Methods for the Examination of Water and Waste Water Including Bottom Sediments and Sludges, 12th edn. New York: American Public Health Association.

Patel, G. B. \& Roth, L. A. (1977). Effect of sodium chloride on growth and methane production by methanogens. Canadian Journal of Microbiology 23, 893-897.

PIRT, S. J. (1975). Principles of Microbe and Cell Cultivation, pp. 199-222. New York: John Wiley. Speece, R. E. \& McCartY, P. L. (1964). Nutrient requirements and biological solids accumulation in anaerobic digestion. Advances in Water Pollution Research, Proceedings of the First International Conference, London, pp. 305-333. Edited by W. W. Eckenfelder. Oxford: Pergamon Press.

VAN Huyssteen, J. J. (1967). Gas chromatographic separation of anaerobic digester gases using porous polymer. Water Research 1, 237-242.

Wolin, E. A., Wolin, M. J. \& Wolfe, R. S. (1963). Formation of methane by bacterial extracts. Journal of Biological Chemistry 238, 2882-2886.

ZeIKUS, J. G. (1977). The biology of methanogenic bacteria. Bacteriological Reviews 41, 514-541. 